\title{
PENGARUH PENERAPAN MODEL PEMBELAJARAN KOOPERATIF TIPE THINK PAIR SHARE DENGAN PENDEKATAN HEURISTIK TERHADAP KEMAMPUAN PEMECAHAN MASALAH MATEMATIS SISWA MTS NEGERI NAUMBAI KECAMATAN KAMPAR
}

\author{
Zulfah \\ Universitas Pahlawan Tuanku Tambusai, Jl. Tuanku Tambusai \\ Email penulis: zulfahasni670@gmail.com
}

\begin{abstract}
The aims of this research is to determine whether there is any difference in mathematical problem solving ability of students who apply cooperative learning model think pair share with a heuristic approach with students who apply conventional learning. This research was a quasi experiment with pretest-posttest control group design. The population in this research were all of the students. The sample in this research were students of class VIII B and VIII C from using random sampling. In this case, a class VIII B used as a control class and class VIII $C$ as the experimental class. Based on the result obtaine by $t$-test calculation $t_{\text {hitung }}=3,95$, with $\alpha=0,05$, and $d f=38$. from distribution list $t$ obtained $t_{\text {tabel }}=2,02$. Based on the result of the data analysis, it can be concluded that there are differences in mathematical problem solving ability of students who implement cooperative learning model think pair share with a heuristic approach with student who apply conventional learning, meaning of existences there are significant differences in the application of learning models.
\end{abstract}

Keywords: Think Pair Share, Heuristic Approach, Problem Solving Ability

\begin{abstract}
Abstrak
Penelitian ini bertujuan untuk mengetahui ada atau tidaknya perbedaan kemampuan pemecahan masalah matematis siswa yang menerapkan model pembelajaran kooperatif tipe Think Pair Share dengan pendekatan Heuristik dengan siswa yang menerapkan pembelajaran konvensional. Penelitian ini merupakan Quasi Eksperimen dengan Pretest-Posttest Control Group Design. Populasi dalam penelitian ini adalah seluruh siswa MTs Negeri Naumbai tahun ajaran 2013/2014. Sampel dalam penelitian ini adalah siswa kelas VIII B dan VIII $C$ yang pengambilannya menggunakan random sampling. Berdasarkan hasil dari perhitungan tes- $t$ diperoleh $t_{\text {hitung }}=3,95$, dengan $\alpha=0,05$ dan $d f=38$ dari daftar distribusi $t$ diperoleh $t_{\text {tabel }}=2,02$. Dari perhitungan didapat $t_{\text {hitung }}=3,95$ jelas berada pada daerah penerimaan $H_{a}$. Berdasarkan hasil analisis data dapat diambil kesimpulan bahwa ada perbedaan kemampuan pemecahan masalah matematis siswa yang menerapkan model pembelajaran kooperatif tipe Think Pair Share dengan pendekatan Heuristik dengan siswa yang menerapkan pembelajaran konvensional. Keywords: Think Pair Share, Pendekatan Heuristik, Kemampuan Pemecahan Masalah
\end{abstract}

Kata kunci: Think Pair Share, Pendekatan Heuristik, Kemampuan Pemecahan Masalah

\section{PENDAHULUAN}

Kemahiran yang diharapkan dalam pembelajaran matematika satu diantaranya adalah kemahiran memecahkan masalah yang merupakan kompetensi strategik yang ditujukan untuk siswa dalam memahami, memilih pendekatan dan strategi pemecahan, dan menyelesaikan model untuk menyelesaikan masalah. Kegiatan belajar yang bertujuan untuk meningkatkan kemahiran pemecahan masalah matematis membuat siswa dapat mengembangkan kemampuannya dalam berpikir. Berpikir termasuk aktivitas kognitif tingkat tinggi yang 
bermanfaat bagi siswa untuk dapat membandingkan atau membedakan sesuatu, merumuskan dan menyelesaikan suatu permasalah, dapat mengeluarkan ide-ide, serta mampu membuat keputusan dalam suatu masalah.

Kurikulum matematika sekolah yang memiliki tujuan agar siswa mampu menghadapi perubahan-perubahan ilmu pengetahuan dan teknologi yang berkembang semakin pesat, mengharuskan guru untuk memberikan pembekalan yang maksimal terhadap siswa, dalam pelaksanaannya di sekolah pembekalan tidaklah cukup hanya dengan kegiatan pembelajaran yang bersifat hapalan, latihan pengerjaan soal yang rutin, serta proses pembelajaran biasa. Oleh sebab itu wajarlah jika pemecahan masalah matematis merupakan bagian yang sangat penting, bahkan paling penting dalam belajar matematika. Siswa diharuskan mempunyai kemampuan dan keterampilan dalam memecahkan masalah yang berhubungan dengan soalsoal matematika, sebagai sarana baginya untuk mengasah penalaran yang cermat, logis, kritis, analitis, dan kreatif.

Namun kenyataannya, masih banyak siswa yang memiliki kemampuan pemecahan masalah matematis yang rendah. Berdasarkan observasi di sekolah dan didukung dengan pernyataan dari guru bidang studi matematika MTs Negeri Naumbai yaitu Ibu Dra. Nopriati, diketahui bahwa siswa kesulitan dalam menyelesaikan soal yang digolongkan masalah. Jika guru memberikan soal yang berbentuk pemecahan masalah kepada siswa, sebagian besar siswa tidak dapat menyelesaikan soal tersebut, siswa terlihat kebingungan dalam memahami soal.

Kegiatan belajar bersifat kelompok juga telah sering diterapkan oleh guru dalam proses belajar mengajarnya, namun kendalanya adalah ketika siswa dibagi kedalam kelompok yang terdiri dari empat atau lima orang, anggota yang berperan aktif menyelesaikan tugas kelompok hanyalah siswa yang memiliki kemampuan lebih dari anggota kelompok yang lain. Hal ini menyebabkan usaha tersebut belum memberikan kemajuan dalam meningkatkan kemampuan pemecahan masalah matematis siswa.

Adapun gejala-gejala yang berkaitan dengan rendahnya kemampuan pemecahan masalah matematis diantaranya:

1. Sebagian besar siswa tidak bisa mengerjakan soal yang berbeda dari contoh soal yang diberikan guru.

2. Sebagian besar siswa tidak bisa memahami soal yang berbentuk soal cerita dengan baik.

3. Sebagian besar siswa tidak bisa menyelesaikan soal-soal aplikasi atau soal-soal pemecahan masalah. 
4. Siswa menjawab soal tanpa menggunakan langkah-langkah umum pemecahan masalah

Berdasarkan gejala-gejala tersebut, maka perlu dilakukan perbaikan dan pembaharuan dalam kegiatan belajar. Tujuan pembelajaran yang biasanya lebih memfokuskan kemampuan siswa dalam menyelesaikan masalah yang bersifat rutin harus dikembangkan lagi sehingga siswa juga memiliki kemampuan dalam pemecahan masalah matematis yang bersifat kompleks. Selain itu, salah satu alternatif perbaikan pada model pembelajaran yang sesuai dengan gejala-gejala tersebut adalah model pembelajaran kooperatif tipe Think Pair Share dan digabungkan dengan menggunakan pendekatan Heuristik.

Model pembelajaran kooperatif merupakan suatu aktivitas pembelajaran yang dapat memberikan siswa kesempatan untuk saling berbagi pemikiran serta solusi dalam memecahkan suatu masalah. Dengan menerapkan model pembelajaran kooperatif tipe Think Pair Share diharapkan dapat meningkatkan partisipasi siswa serta memberikan lebih banyak kesempatan kontribusi pada masing-masing anggota kelompok, hal ini dikarenakan model pembelajaran kooperatif tipe Think Pair Share ini hanya beranggotakan dua orang siswa. Selain itu Wina Sanjaya mengemukakan bahwa "Pembelajaran kooperatif dapat merealisasikan kebutuhan siswa dalam berpikir, memecahkan masalah, dan mengintegrasikan pengetahuan." Pendapat ini juga dikemukakan oleh Noraini Idris yang menyatakan bahwa pembelajaran kooperatif merupakan salah satu kaedah yang sangat berkesan dalam perkembangan kemahiran berpikir. Dalam kaedah ini siswa yang dikumpulkan dalam tim, berkongsi pengetahuan dan pengalaman untuk menyelesaikan suatu masalah atau untuk memahami sesuatu.

Melalui penggabungan antara model pembelajaran kooperatif tipe Think Pair Share dengan pendekatan Heuristik ini diharapkan dapat membuat kemampuan pemecahan masalah matematis siswa meningkat secara signifikan. Pendekatan Heuristik merupakan suatu pendekatan yang tujuannya adalah untuk mengajarkan keterampilan pemecahan masalah tertentu, yang dapat digunakan siswa ketika mereka mengatasi masalah tertentu. Oleh karena itu peneliti tertarik untuk mengangkat judul "Pengaruh Penerapan Model Pembelajaran Kooperatif Tipe Think Pair Share dengan Pendekatan Heuristik Terhadap Kemampuan Pemecahan Masalah Matematis Siswa MTs Negeri Naumbai Kecamatan Kampar Kabupaten Kampar”. 


\section{Rumusan Masalah}

Berdasarkan latar belakang dan batasan masalah yang telah dipaparkan sebelumnya, maka rumusan masalah dalam penelitian ini adalah: "Apakah terdapat perbedaan kemampuan pemecahan masalah matematis siswa yang menerapkan model pembelajaran kooperatif tipe Think Pair Share dengan pendekatan Heuristik dengan siswa yang menerapkan pembelajaran konvensional?".

\section{Kemampuan Pemecahan Masalah}

Agar memahami apa yang dimaksud dengan kemampuan pemecahan masalah, kita terlebih dahulu harus mengetahui apa itu masalah. Masalah dalam KBBI didefinisikan sebagai "sesuatu yang harus diselesaikan atau dipecahkan." Suatu pertanyaan akan merupakan suatu masalah hanya jika seseorang tidak mempunyai aturan/hukum tertentu yang segera dapat dipergunakan untuk menemukan jawaban pertanyaan tersebut. Selanjutnya masalah menurut sebagian ahli matematika merupakan pertanyaan yang harus dijawab dan direspon, namun demikian, tidak semua pertanyaan secara otomatis akan langsung menjadi masalah.

Suatu pertanyaan akan menjadi masalah jika pertanyaan tersebut menunjukkan adanya suatu tantangan yang tidak dapat diselesaikan hanya dengan menggunakan cara atau prosedur rutin yang sudah dikenali oleh siswa. Dalam pembelajaran matematika setiap penugasan untuk siswa dapat digolongkan menjadi dua hal yaitu latihan dan masalah. Latihan merupakan tugas yang langkah penyelesaiannya sudah diketahui siswa. Pada umumnya suatu latihan dapat diselesaikan dengan menerapkan secara langsung satu atau lebih algoritma. Sedangkan masalah dalam matematika bersifat lebih kompleks dari pada latihan karena strategi untuk menyelesaikannya tidak langsung tampak. Dalam menyelesaikan masalah siswa dituntut kreativitasnya. Berdasarkan uraian tersebut, maka masalah dalam matematika merupakan suatu persoalan yang harus diselesaikan atau dipecahkan dengan menggunakan prosedur penyelesaian yang tidak rutin yang mana langkah penyelesaiannya harus diolah sendiri oleh siswa.

Setelah mengetahui apa itu masalah, selanjutnya kita akan membahas mengenai pemecahan masalah. Pemecahan masalah adalah proses menerapkan pengetahuan yang telah diperoleh sebelumnya ke dalam situasi baru yang belum dikenal. Pemecahan masalah juga didefinisikan sebagai usaha mencari jalan keluar dari suatu kesulitan, mencapai suatu tujuan yang tidak dengan segera dapat dicapai. Karena pemecahan masalah merupakan suatu tingkat 
aktivitas intelektual yang tinggi. Pemecahan masalah dalam matematika termasuk proses menemukan jawaban dari suatu pertanyaan yang membutuhkan prosedur atau langkah yang tidak rutin dan terdapat dalam suatu bentuk teks, teka-teki non rutin dan situasi-situasi dalam kehidupan nyata. Masalah-masalah yang dipecahkan meliputi semua topik dalam matematika, mulai dari geometri, pengukuran, aljabar, bilangan (aritmatika) maupun statistik. Pemecahan masalah harus didasarkan atas adanya struktur kognitif yang dimiliki siswa. Bila tidak didasarkan atas struktur kognitif, siswa mempunyai kemungkinan kecil untuk dapat menyelesaikan masalah yang disajikan.

\section{Pembelajaran Kooperatif Tipe Think Pair Share}

Think Pair Share atau dalam bahasa indonesia berpikir, berpasangan, berbagi pertama kali dikembangkan oleh Frang Lyman dan koleganya dari Universitas Maryland pada tahun 1985. Arends yang dikutip Trianto menyatakan bahwa Think Pair Share merupakan suatu cara yang efektif untuk membuat variasi suasana pola diskusi kelas, dengan asumsi bahwa semua resitasi atau diskusi membutuhkan pengaturan untuk mengendalikan kelas secara keseluruhan. Prosedur yang digunakan dalam Think Pair Share dapat memberikan siswa lebih banyak waktu berpikir, untuk merespon dan saling membantu. Suprijono yang dikutip Muhammad Thobroni dan Arif Mustofa menyatakan bahwa Think Pair Share memiliki makna sebagai berikut:

1) Thinking, siswa diberi kesempatan untuk memikirkan ide-ide mereka tentang pertanyaan atau wacana yang diberikan oleh guru.

2) Pairing, siswa menentukan dengan siapa mereka akan berpasangan dengan tujuan agar siswa dapat berdiskusi dan mendalami ide-ide yang telah ditemukan masing-masing siswa.

3) Sharing, setelah ditemukan kesepakatan ide-ide pada masing-masing kelompok, lalu pada tahap ini ide-ide tersebut dibagikan kepada kelompok lain melalui kegiatan diskusi dan tanya jawab. Hal tersebut dimaksudkan agar dari berbagai ide-ide yang mereka temukan, dapat ditemukan satu struktur yang integratif dari pengetahuan yang telah dipelajari.

Model pembelajaran kooperatif tipe Think Pair Share memberikan siswa kesempatan untuk bekerja sendiri dalam memecahkan masalah yang diberikan guru serta kesempatan untuk bekerja sama di dalam kelompok. Model pembelajaran kooperatif tipe Think Pair Share ini menghendaki siswa untuk belajar saling membantu dalam kelompok kecil yang heterogen.

Penerapan model pembelajaran kooperatif tipe Think Pair Share membuat guru dapat memberikan sedikitnya delapan kali lebih banyak kesempatan kepada setiap siswanya untuk dikenali dan menunjukkan partisipasi mereka kepada orang lain, selain itu siswa juga akan 
dibelajarkan untuk menyampaikan pendapat dan ide-ide mereka kepada siswa-siswa yang lain. Model pembelajaran kooperatif tipe Think Pair Share ini bisa digunakan oleh setiap guru dalam semua mata pelajaran dan untuk semua tingkatan usia anak didik.

Menurut Trianto terdapat tiga tahap dalam melaksanakan pembelajaran kooperatif tipe Think Pair Share ini, yaitu:

1) Langkah 1: Berpikir (Thinking)

Guru mengajukan suatu pertanyaan atau masalah yang dikaitkan dengan pelajaran, dan meminta siswa menggunakan waktu beberapa menit untuk berpikir sendiri jawaban atau masalah. Siswa membutuhkan penjelasan bahwa berbicara atau mengerjakan bukan bagian berpikir.

2) Langkah 2: Berpasangan (Pairing)

Selanjutnya guru meminta siswa berpasangan dan mendiskusikan apa yang telah mereka peroleh. Interaksi selama waktu yang disediakan dapat menyatukan gagasan apabila suatu masalah khusus yang diidentifikasi Secara normal guru memberi waktu tidak lebih dari 4 atau 5 menit untuk berpasangan.

3) Langkah 3: Berbagi (Sharing)

Pada langkah akhir, guru meminta pasangan-pasngan untuk berbagi dengan keseluruhan kelas yang telah mereka bicarakan. Hal ini efektif untuk berkeliling ruangan dari pasangan mendapat kesempatan untuk melaporkan.

\section{Pendekatan Heuristik}

Pendekatan menurut KBBI adalah "usaha dalam rangka aktivitas penelitian untuk mengadakan hubungan dengan orang yang akan diteliti, dan metode untuk mencapai pengertian tentang masalah yang diteliti." Sedangkan Heuristik (heuristis) dalam KBBI bersangkutan dengan prosedur analitis yang dimulai dengan perkiraan yang tepat dan mengecek ulang sebelum memberi kepastian. Heuristik bisa didefinisikan sebagai sebuah pendekatan, strategi, teknik ataupun aturan-aturan dalam pemecahan masalah.

Pendekatan Heuristik bertujuan untuk mengajarkan keterampilan mengatasi masalah. Heuristik adalah suatu langkah-langkah umum yang memandu pemecah masalah dalam menemukan solusi masalah. Heuristik bertujuan untuk memandu siswa dalam menemukan solusi. Pengajaran keterampilan berpikir dan mengatasi masalah sudah sejak lama menjadi fokus yang sangat utama di berbagai sekolah di dunia. Hal ini menurut Resnick yang dikutip Daniel Muijs dan David Reynolds sebagian disebabkan oleh berbagai penelitian yang 
menunjukkan adanya keterkaitan antara keterampilan berpikir siswa dan prestasinya diberbagai mata pelajaran di sekolah seperti mata pelajaran matematika, dan sebagian lainnya disebabkan oleh adanya berbagai perubahan terjadi di masyarakat, khususnya perubahan yang bergerak ke arah masyarakat dimana pengetahuan dan informasi semakin membludak. Hal ini menunjukkan bahwa memproses sejumlah besar pengetahuan yang ada saja tidak cukup. Siswa diharuskan memiliki keterampilan untuk membuat pilihan-pilihan dan mengatasi berbagai masalah dengan menggunakan penalaran logis.

Berdasarkan alasan tersebut, diperlukan suatu pendekatan yang mampu meningkatkan keterampilan pemecahan masalah siswa. Salah satu pendekatan yang populer adalah mengajarkan keterampilan mengatasi masalah kepada siswa yang disebut pendekatan Heuristik. Banyak penelitian tentang paradigma ini yang dilakukan dalam kaitannya dengan penyelesaian masalah yang terkait dengan kata-kata, misalnya pertanyaan matematika dalam bentuk konteks.

\section{Heuristik dalam Pemecahan masalah Matematis}

Heuristik merupakan langkah-langkah umum yang memandu pemecah masalah dalam menemukan solusi masalah. Terdapat beberapa model Heuristik yang telah dikemukakan oleh para ahli diantaranya adalah:

1) Model Heuristik Polya

Model yang paling populer mengenai pemecahan masalah adalah model Polya. Dimana Polya mencanangkan empat langkah pemecahan masalah matematika:

a) Memahami masalah yaitu melibatkan proses membaca dan mengkaji permasalahan untuk memahami data yang diberikan data yang diperlukan.

b) Membentuk rancangan penyelesaian yaitu melibatkan proses mencari hubungan antara data yang diberi dengan apa yang dikehendaki.

c) Melaksanakan rancangan penyelesaian, yaitu melibatkan proses melaksanakan penyelesaian yang dirancang dengan berhati-hati untuk memperoleh jawaban yang dikehendaki.

d) Meneliti semua pemecahan, yaitu melibatkan penelitian pemecahan untuk menentukan apakah ada pemecahan itu.

2) Model Heuristik Wickelgren

Model Heuristik ini merupakan perincian dari Heuristik Polya yang terdiri dari empat langkah pemecahan masalah, yaitu:

a) Menganalisis dan memahami masalah (Analyzing and understanding a problem) 
(1) Membuat gambar atau ilustrasi jika memungkinkan

(2) Mencari kasus khusus

(3) Mencoba memahami masalah secara sederhana.

b) Merancang dan merencanakan solusi (Designing and planning a solution)

(1) Merencanakan solusi secara sistematis

(2) Menentukan apa yang akan dilakukan, bagaimana melakukannya serta hasil yang diharapkan

c) Mencari solusi dari masalah (Exploring solution to difficult problem)

(1) Menentukan berbagai masalah yang ekivalen, yaitu: penggantian kondisi dengan yang ekivalen; menyusun kembali bagian-bagian masalah dengan cara yang berbeda; menambah bagian yang diperlukan; serta memformulasikan kembali masalah.

(2) Menentukan dan melakukan memodifikasi secara lebih sederhana dari masalah sebenarnya yaitu: memilih tujuan antara dan mencoba memecahkannya; mencoba lagi mencari solusi akhir; dan memecahkan soal secara bertahap.

(3) Menentukan dan melakukan memodifikasi secara umum dari masalah sebenarnya, yaitu: memecahkan masalah yang analog dengan variabel yang lebih sedikit; mencoba menyelesaikan dengan kondisi satu varibel; serta memecahkan masalah melalui masalah yang mirip.

d) Memeriksa Solusi (Veriying a solution)

(1) Menggunakan pemeriksaan secara khusus terhadap setiap informasi dan langkah penyelesaian.

(2) Menggunakan pemeriksaan secara umum untuk mengetahui masalah secara umum dan pengembangannya.

\section{METODE PENELITIAN}

Penelitian ini merupakan Quasi Eksperimen, hal ini disebabkan peneliti tidak mampu mengontrol sepenuhnya variabel-variabel yang mungkin dapat mempengaruhi kemampuan pemecahan masalah matematis siswa. Akan tetapi dalam pelaksanaannya, peneliti juga menerapkan desain eksperimen murni karena ciri utama dari desain eksperimen murni yaitu sampel yang digunakan untuk kelompok kontrol maupun kelompok eksperimen dipilih secara random.

Adapun desain yang digunakan adalah Pretest-Posttest Control Group Design. Dalam desain ini seluruh siswa kelas VIII diberi pretest untuk mengetahui keadaan awal ada atau tidaknya perbedaan antara kelompok eksperimen dan kelompok kontrol pada 
kemampuan pemecahan masalah matematis. Hasil pretest yang baik bila nilai kelompok eksperimen tidak berbeda secara signifikan. Populasi dalam penelitian ini adalah seluruh siswa MTs Negeri Naumbai tahun ajaran 2013/2014 yang berjumlah 180 orang. Akan tetapi dikarenakan siswa kelas VII sedang dalam masa pendekatan dengan gurunya serta siswa kelas IX akan menghadapi ujian nasional dan materi yang akan diteliti dipelajari di kelas VIII, maka populasi dalam penelitian ini adalah seluruh siswa kelas VIII yang berjumlah 60 orang.

\section{HASIL PENELITIAN}

Berdasarkan hasil penelitian yang telah dilakukan oleh peneliti diperoleh kemampuan pemecahan masalah matematis siswa yang menerapkan model pembelajaran kooperatif tipe Think Pair Share dengan pendekatan Heuristik mengalami peningkatan, siswa yang awalnya kesulitan dalam memahami soal, setelah menerapkan model pembelajaran kooperatif tipe Think Pair Share dengan pendekatan Heuristik, siswa-siswa tersebut sudah mulai bisa memahami masalah yang berbentuk soal cerita. Siswa juga telah memahami langkah-langkah dalam menyelesaikan pemecahan masalah. Siswa juga mengalami kemajuan dalam menyelesaikan soal yang diberikan guru yang mana soal tersebut berbeda dari contoh soal sebelumnya.

Berdasarkan hasil perhitungan tes kemampuan pemecahan masalah matematis siswa pada materi lingkaran diperoleh rata-rata kemampuan pemecahan masalah matematis siswa yang menerapkan model pembelajaran kooperatif tipe Think Pair Share dengan pendekatan Heuristik adalah 65,9 lebih tinggi dari pada rata-rata kemampuan pemecahan masalah siswa yang menerapkan pembelajaran konvensional yaitu 51,1. Jika rata-rata nilai kelas eksperimen lebih baik dari pada kelas kontrol, maka perlakuan (treatment) yang diberikan pada kelompok eksperimen berpengaruh positif. Hal ini sejalan dengan yang dikemukakan oleh Sugiyono bahwa jika kelompok treatment lebih baik dari pada kelompok kontrol maka perlakuan yang diberikan berpengaruh positif.

Hasil pengujian hipotesis memperoleh temuan adanya perbedaan kemampuan pemecahan masalah matematis siswa yang menerapkan model pembelajaran kooperatif tipe Think Pair Share dengan pendekatan Heuristik dengan siswa yang menerapkan model pembelajaran konvensional dengan $t_{\text {hitung }}$ sebesar 3,9 dan $t_{\text {tabel }}$ sebesar 2,02. Hasil penelitian ini menunjukkan bahwa model pembelajaran kooperatif tipe Think Pair Share 
dengan pendekatan Heuristik cukup efektif untuk melatih kemampuan pemecahan masalah matematis siswa.

\section{DAFTAR PUSTAKA}

Agus Suprijono. 2012. Cooperative Learning; Teori dan Aplikasi PAIKEM. Yogyakarta: Pustaka Pelajar.

Anita Lie. 2008. Cooperative Learning. Jakarta: PT Gramedia Widiasarana.

Buchari Alma. 2010. Guru Profesional. Bandung: Alfabeta.

BNSP. 2006. Model Penilaian Kelas. Jakarta: Depdiknas

Daniel Muijs dan David Reynolds. 2008. Effective Teaching (Teori dan Aplikasi). Yogyakarta: Pustaka Pelajar.

Djamilah Bondan Widjajanti. 2009. Kemampuan Pemecahan Masalah Matematis Mahasiswa Calon Guru Matematika: Apa Dan Bagaimana Mengembangkannya, Seminar Nasional Matematika dan Pendidikan Matematika, tersedia dalam: www.google.com/P25-Djamilah Bondan Widjajanti.pdf. Didownload pada tanggal 7 Maret 2013.

Dindin Abdul Muiz Lidinillah. Heuristik Dalam Pemecahan Masalah Matematika dan Pembelajarannya di Sekolah dasar. tersedia dalam: http://www.google.co.id/heuristikpemecahanmasalah.pdf. Didownload pada tanggal 27 April 2013.

Effendi Zakaria, dkk. 2007. Trend Pengajaran dan Pembelajaran Matematik, Kuala Lumpur: PRIN-AD SDN. BHD.

Fajar Shadiq. 2004. Pemecahan masalah, penalaran dan komunikasi (Yogyakarta: Depdiknas, 2004), tersedia dalam: www.google.co.id/pemecahanmasalah.pdf. Didownload pada tanggal 17 April 2013.

Gimin, dkk. 2008. Model-model Pembelajaran. Pekanbaru: Cendikia Insani.

Goenawan Roebyanto dan Aning Wida Yanti, Langkah-langkah

Umum dalam Pemecahan Masalah-Unit 3. tersedia dalam: http://pjijpgsd.dikti.go.id/pemecahanmasalah. Didownload pada tanggal 3 April 2013. Hartono. 2011. Metodologi Penelitian, Pekanbaru: Zanafa Publishing. 2012. Statistik Untuk Penelitian, Yogyakarta: Pustaka Pelajar.

Herman Hudojo. 2005. Pengembangan Kurikulum dan Pembelajaran Matematika. Malang: Penerbit Universitas Negeri Malang. 
Mas'ud Zein. 2011. Evaluasi Pembelajaran Analisis Soal Essay, Makalah dalam Bentuk Power Point (Tidak Diterbitkan).

Muhammad Yaumi. 2012. Pembelajaran Berbasis Multiple Intelligence. Jakarta: Dian Rakyat.

Muhammad Thobroni dan Arif Mustofa. 2012. Belajar dan Pembelajaran: Pengembangan Wacana dan Praktik Pembelajaran dalam Pembangunan Nasional. Yogyakarta: ArRuzz Media.

Nana Syaodih Sukmadinata. 2010. Metode Penelitian Pendidikan. Bandung: PT Remaja Rosda Karya.

Noraini Idris. Pedagogi dalam Pendidikan Matematik. Kuala Lumpur: Utusan Publications \& Distributors Sdn Bhd.

Riduwan. 2010. Belajar Mudah (Penelitian Untuk Guru, Karyawan, dan Peneliti Pemula). Alfabeta: Bandung. 2003. Dasar-Dasar Statistik. Bandung: Alfabeta.

Risnawati. 2008. Strategi Pembelajaran Matematika. Pekanbaru: Suska Press.

Roestiyah, N.K. 2008. Strategi Belajar Mengajar. Jakarta: Rineka Cipta.

Slavin, Robert E. 2005. Cooperative Learning Teori, Riset dan Praktik. Bandung: Nusa Media.

Sri Wardhani. 2008. Analisis SI dan SKL Mata Pelajaran Matematika SMP/MTs untuk Optimaisasi Tujuan Mata Pelajaran Matematika. Yogyakarta:Pusat Pengembangan dan Pemberdayaan Pendidikan dan Tenaga Kependidikan Matematika.

Suharsimi Arikunto 2008. Dasar-dasar Evaluasi Pendidikan. Jakarta: Bumi Aksara.

Sugiyono. 2010. Metode Penelitian Kuantitatif Kualitatif dan $R \& D$, Bandung: Alfabeta.

Supranata, Sumarna. 2009. Analisis Validitas, Reliabilitas dan Interpretasi Hasil Tes Implementasi Kurikulum 2004. Bandung: PT Remaja Rosdakarya.

Sudjimat, D.A. 1995. Pembelajaran pemecahan Masalah: Tinjauan singkat Berdasarkan teori Kognitif. Jurnal Pendidikan Matematika dan Sains, Malang: IKIP Malang.

Tim MKPBM Jurusan Pendidikan Matematika. 2001. Common Text Book; Strategi Pembelajaran Matematika Kontemporer. Bandung: Penerbit JICA-Universitas Pendidikan Indonesia (UPI).

Tim Pusat Bahasa. 2008. Kamus Besar Bahasa Indonesia Pusat Bahasa; Edisi Keempat. Jakarta: PT Gramedia Pustaka Utama.

Trianto. 2010. Mendesain Model Pembelajaran Inovatif - Progresif. Jakarta: Kencana. 
12 Jurnal Cendekia: Jurnal Pendidikan Matematika, Volume 01, No. 2, November 2017 hal. 1 - 12

Wina Sanjaya. 2006. Strategi Pembelajaran Berorientasi Standar Proses Pendidikan. Jakarta: Kencana. 